\title{
Impact of Information Technology on the HR Practices in the Public Sector: Evidence from the Republic of Kosovo
}

\author{
Hamdi HOTI*1, Arbër H. HOTI ${ }^{2}$, Edisona KURHASKU ${ }^{3}$
}

\begin{abstract}
Nowadays, people are the most difficult beings to manage due to their complexity and complex nature. Human Resources in the public sector are structures that we must provide impartial treatment, ethical standards, and promote a value-based system. Human Resource Management (HRM) plays an important role in the development of a country, and in particular, in the implementation of strategic activities for the civil service in Public Administration. Recently, Information Technology (IT) has impacted all actions of society, as well as organizational processes including HRM processes and practices.

Currently, Information Technologya is making great changes, starting from the fact that it is impacting the public sector workers to attend training, in order for them to acquire different skills such as using IT developments, gaining new knowledge, skills, and using programs in different fields where more productive and profitable results are obtained. In this research paper, we have used two statistical extraction techniques which are OneWay ANOVA and Chi Square, which show that there is no difference between groups in the acquisition of the institution's policies, and also expresses the significance of the relationship between the main issues of active employees in developing knowledge in the use of IT in the public sector.
\end{abstract}

Keywords: Human Resources, Management, Public Sector, Information Technology, Development, etc.

\section{Introduction}

Human Resource Management (HRM) in the public sector should be specialized in terms of management, owing to the fact that deals with the development and effective use of intellectual capital as a resource, towards reaching and achieving objectives of the organization.

The paper aims to present the theoretical and practical contribution to the application of IT and provides guidance for future research in this field. Given the importance of IT application in the public sector in the country, we conducted the research entitled: The impact of Information Technology on the HR Practices in the Public Sector: Evidence from Republic of Kosovo. This paper focuses on ways of managing employees in the public sector and also raises the issue on how to stimulate them in the implementation of IT, as a way of achieving a high level of performance in Public Administration, where we 
would ensure a sufficient number of employees in the right place in order to achieve higher efficiency at work.

The paper highlights the application of IT in the public sector, how well informed are the Human Resources in this sector, what are their opinions about the importance of IT in performing tasks, and in particular the impact that IT has on the daily work in the public sector nowadays. Today, Human Resource Management includes many activities such as: Recruitment, Selection, Training,

and Rewarding for the performance of employees in the organization. Human Resource Management aims to achieve competition in the field of Human Resource Management by providing ongoing educational and training programs and applications for the personal and professional development of the organization's employees (Niaz, 2020). Human resource management, including management's main responsibilities in each Organization and all levels of managers, have some of this responsibility (Kumar, 2014).

A functional public administration is a prerequisite for democratic, transparent, and effective governance. As the foundation of the functioning of state, it determines the ability of the government to provide public services and to cultivate competition and development of the country. It also plays a crucial role in the European integration process, enabling the implementation of fundamental reforms and organizing an effective dialogue on European Union membership.

Therefore, the EU enlargement criteria recognizes and emphasizes the need for the country to establish a state public administration that has the capacity to follow the principles of good governance and that makes transposition and effective implementation of acquis communautaire according (Comission, 2015).

The European Commission (EC) has strengthened its focus on public administration reform by highlighting the six key reform issues and better integrating reform into the enlargement process through specific Public Administration Reform Groups and stronger links with accession/membership negotiations. The six main areas of reform identified by the Commission form the basis of the Principles of Public Administration (Comission, 2015).

Strengthening institutions also include building the capacity of Human Resources and their capabilities, continuous stimulation of this category and other treatments respecting EU standards in this area (Services, 2015). The analysis of the capacity building process in public administration is really necessary to understand what our institutions can achieve in reality. It is understandable that the rapidly changing nature of technology will present the necessity of change, but also risks to the process (Services, 2015).

Information technology in Republic of Kosovo has experienced rapid development since 1999, whereas today, Kosovar organizations in the field of IT offer a wide range of IT services. Kosovo is known for the youngest population in Europe who have advanced knowledge in the field of IT, since the application of IT in jobs from Human Resources in the public sector has an impact on the development of the country, since the majority of HR departments in the public sector today use IT applications and products to implement the tasks and responsibilities they have in the workplace. 


\section{Literature review}

The performance of an enterprise depends heavily on finding the right people to work for them, to guide the selected employee and to ensure their needs (Arta JASHARI, Enver KUTLLOVCI, 2020). Human Resource Information System (HRIS) is a Human Resource Management (HRM) tool that enables an organization to design and manage a comprehensive human resources strategy through information technology (Alam., 2017) (Dery, K., Grant, D., \& Wiblen, S, 2014) (Try Hikmawan, Budi Santoso, July 2020). Also, according to (Try Hikmawan, Budi Santoso, July 2020) one of the services provided by implementing the human resource information system (HRIS). Human resource information system is "System used to acquire, store, manipulate, analyze, retrieve, and distribute information regarding an organization's human resources. Human resources information system aims to provide answers to overcome the problems faced by the company in improving the performance of its employees so that the performance set by the company can be achieved (Try Hikmawan, Budi Santoso, July 2020).”

\section{Information Technology concepts}

Information technology is a process that uses a combination of tools and methods of collecting, processing and transmitting data to obtain new and qualitative information about the state of an object, process or phenomenon. Information Technology (IT) is the application of computers \& telecommunication devices to store, retrieve, transmit and shaped data, usually in the background of a business or other organizations.

This term is commonly used as an equivalent for computers \& computer networks, but also encircles other information delivery technologies such as radio, television and mobiles (Kumar, 2014).

Nowadays, the application of IT in HRM in the public sector, its impact and use for the development of Human Resources has greatly increased the speed and ease of carrying out HR activities, and at the same time, has reduced the time of completion of works, the greater quantity and safety of work.

The concepts of Technology and Information Technology, lie mainly in the fact that the basis of both is the process, which is understood as a certain set of actions aimed at achieving the goal. At the same time, each Technological process must be determined by the strategy chosen by a person and implemented using a combination of different methods and tools. Information Technology methods are methods of processing and transmitting information. Information Technology tools are the technical, software, information and other tools by which Information Technology is implemented in an economic structure.

Technology is the set of processes, equipment, techniques, tools, methods and capabilities that provide a product or service. Information technology is also a thinking strategy and instrument with innovation in the field of Human Resources.

Information technology is formed by combining and connecting series of useful schemes produced and supercomputers, computers, cables and wires. Thus, Information Technology means the system of origin and collection of information using society and 
organization. Information Technology made it possible to access information from anywhere, making computer software cheaper, easier and smaller (Rohilla, 2017).

\section{Information Systems in Human Resources Management}

Information systems generally have a major impact on HRM because they transform HR processes and practices primarily in terms of how organizations collect, store, use and disseminate information. Ongoing innovations in Technology will radically change the way of working with Human Resources (Stone D, Deadrick D, Lukaszewski K, Johnson R, 2015). The Human Resource Management Information System aims to enhance the efficiency of Human Resource Management as well as the quality of work in the public sector. As Bill Gates puts it "Business and Information Technology have become inseparable. Nobody can talk seriously about one of them without mentioning the other."

Therefore, HR quality is a key success factor for public sector organizations. Human Resources in the public sector must analyze and take into account the social, economic, technological, political and legal environment. Employees should therefore help organizations define strategies and create programs to develop enterprise human capital. The goal of the Human Resources enterprise is to attract, select, motivate and retain skilled employees in the workplace, where: Technology has transformed the way Human Resource processes are managed and how organizations collect, store, use and disseminate information in regards to Human Resources. Information systems have increased HRM efficiency through effective methods of Recruitment, organizational communication, employee involvement and enhanced skills of Human Resources managers (Wilkerson, 2015.). Areas of Human Resource Management should be linked to human capital strategies with the most appropriate technological solutions.

This means to create an E-HR (electronic human resources) organization focused on connecting people with business strategy, to achieve rapid adaptation to changing common needs of people and business (Marlene Sofia Alves e Silva, Carlos Guilherme da Silva Lima, 2017).

\section{The role of Human Resources Management Information System}

The rapid development of IT in these modern times has greatly influenced the rapid development of Human Resources. Currently, Human Resources in the Public Sector in the country, are facing many challenges, and it is important to prepare civil servants to use the facilities/ Information Technology gadgets, because today society is characterized by a high level of development of IT and the use of Technological equipment. Therefore, Information Technology is one of the most important factors of all human activities. The development of IT enabled creation of an environment based on information and real-time interaction. Personnel information systems have evolved from automated employee registration keeping more complex reporting and decision systems (Dr. Prashanth R. Kaninga et al., 2014).

It was proven that Information and Communication Technology (ICT), such as: Internet, mobile communication, and new media in Human Resources are contributing to the 
implementation of the personnel policies of the organizations. The advancement of Information Technology has a great impact on the Human Resources department of Budget Organizations.

Nowadays, organizations have realized that effective recruitment cannot be done without the use of IT. Organizations now use job portals on the internet to search for the best candidates for the position.

The process has been made effective with the use of the internet as many people come to know of the offer and hence increases the probability of hiring efficient employees (Niaz, 2020).

Regarding the HR, today Information Technology assists employees in all processes from Recruitment, Selection, formation and development to retirement, where technology has changed the way managers and employees gain access to HR data. However, today it is a great challenge use Information Technology as an important tool of Human Resources due to its complexity, but if these type of technology are used well, companies save time and money during the work process.

\section{Empirical Analysis - Results}

The results obtained from the survey through electronic platform Google Forms in the research show a favorable situation. The survey is semi-structured and tends to produce answers that provide real results regarding the impact of IT on Human Resources and the work of state institutions.

The research conducted through the survey is divided into two parts:

\section{$\checkmark \quad$ Demographic part; \\ Professional part.}

This survey included 58 participants who were in decision-making duties and responsibilities or part of Human Resources investments in public institutions of Kosovo. We have chosen 58 participants on this survey because they are the only employeeson companies where they have managerial responsibility.

Whereas, in the demographic part, it will be pointed out to whom this survey is addressed, the vast majority of which turn out to be male with an average age of 26-35 years, which gives hope that the impact of IT may be direct and more easily accepted from this category. The surveyed gender turns out to be $83.3 \%$ male and $16.7 \%$ female, while, in the tables presented in the demographic part, in addition to the visual presentation, we have displayed the frequency, percentage, valid percentage and cumulative percentage for the following results. 


\section{Gender}

54 responses

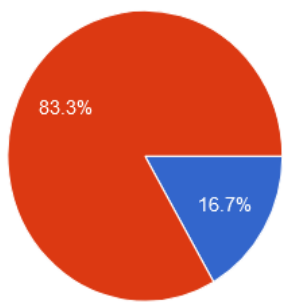

Female

Male

Graph 1: Gender, (Source: Author's 2020)

\section{Gender?}

Table 1: Respondent's gender taken from SPSS analysis, (Source: Author's 2020)

\begin{tabular}{|l|l|l|l|l|l|}
\hline \multirow{2}{*}{ Valid } & Frequency & Percent & Valid Percent & Cumulative Percent \\
\cline { 2 - 7 } & Male & 45 & 16.1 & 16.7 & 16.7 \\
\cline { 2 - 6 } & Total & 54 & 80.4 & 83.3 & 100.0 \\
\hline Missing & System & 2 & 96.4 & 100.0 & \\
\hline Total & 56 & 3.6 & & \\
\hline
\end{tabular}

Table 2: Respondent's age taken from SPSS analysis, (Source: Author's 2020)

Age?

\begin{tabular}{|l|l|l|l|l|l|}
\hline \multicolumn{2}{|c|}{} & Frequency & Percent & Valid Percent & Cumulative Percent \\
\hline \multirow{5}{*}{ Valid } & $18-25$ & 13 & 23.2 & 25.5 & 24.1 \\
\cline { 2 - 6 } & $26-35$ & 19 & 33.9 & 34.5 & 59.3 \\
\cline { 2 - 6 } & $36-45$ & 6 & 10.7 & 10.9 & 70.4 \\
\cline { 2 - 6 } & Over 45 & 16 & 28.6 & 29.1 & 100.0 \\
\cline { 2 - 6 } & Total & 54 & 96.4 & 100.0 & \\
\hline Missing & System & 2 & 3.6 & & \\
\hline Total & 56 & 100.0 & & \\
\hline
\end{tabular}

From 56 respondents $34.5 \%$ are of the age 26-35 years old, 29.1\% are over 45 years old, and $25.5 \%$ are of the age $18-25$, whereas the lowest percentage are of the age 36-45 years old. 
Age?

55 responses

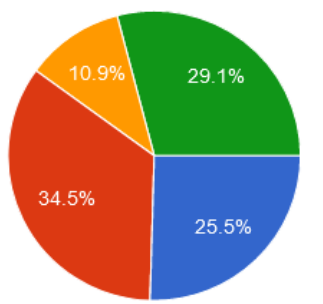

18-25 years;

26-35 vears:

36-45 years:

Over 45 years;

Graph 2: Age, (Source: Author's 2020)

The education level of the respondents includes the level of secondary education with $3.7 \%$ and continues with $23.6 \%$ with $\mathrm{PhD}$ level (who are supposed to be $\mathrm{PhD}$ or $\mathrm{PhDc}$ ), with $32.7 \%$ with Bachelor and $40 \%$ with Master degree.

\section{Education level?}

55 responses

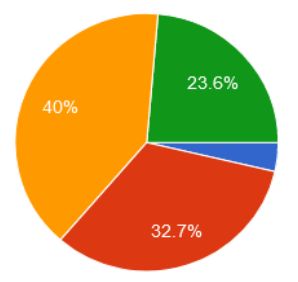

Secondary school;

Bachelor;

Master;

Dr.Sc / PhD.

Graph 3: Education Level, (Source: Author's 2020)

Below is the statistical situation from SPSS for the level of respondents as employees who are monitored and their work is monitored by Human Resources as a key point for recruitment and promotion in the institution where they work.

Table 3: Respondent's education level taken from SPSS analysis, (Source: Author's 2020)

\begin{tabular}{|l|l|l|l|l|l|}
\hline \multicolumn{2}{|c|}{ Education level? } & Frequency & Percent & Valid Percent & Cumulative Percent \\
\hline \multirow{3}{*}{ Valid } & Primary school & 3 & 5.4 & 3.7 & 5.5 \\
\cline { 2 - 6 } & Bsc. Level & 17 & 30.4 & 32.7 & 36.4 \\
\cline { 2 - 6 } & Msc Level & 22 & 39.3 & 40.0 & 76.4 \\
\cline { 2 - 6 } & PhD Level & 13 & 23.2 & 23.6 & 100.0 \\
\cline { 2 - 6 } & Total & 55 & 98.2 & 100.0 & \\
\hline Missing & System & 1 & 1.8 & & \\
\hline Total & 56 & 100.0 & & \\
\hline
\end{tabular}


Below are the general results related to all questions where some of them are standard deviation, mode, median, rank etc. From all the professional questions, the second question was presented with the highest standard deviation of 0.825 , while question 9 has values of 0.401 , another very important part in this research extracted through general statistics is the variance of which in the second question is presented with the highest value in this research from all other questions with the value 0.681 , while with the lowest value, the variance appears in question 9 with the value 0.161 .

Table 4: General Statistics of questions (Source: Authors' 2020)

Frequencies General Frequencies Table

\begin{tabular}{|c|c|c|c|c|c|c|c|c|c|c|c|}
\hline & & $\begin{array}{l}\text { 1. Do } \\
\text { you } \\
\text { think } \\
\text { that IT } \\
\text { will } \\
\text { replace } \\
\text { your } \\
\text { work? }\end{array}$ & $\begin{array}{l}\text { 2. Do } \\
\text { you } \\
\text { feel } \\
\text { endang } \\
\text { ered by } \\
\text { IT } \\
\text { which } \\
\text { can } \\
\text { take } \\
\text { your } \\
\text { place } \\
\text { of } \\
\text { work? }\end{array}$ & $\begin{array}{l}3 . \\
\text { What } \\
\text { level } \\
\text { do you } \\
\text { belong } \\
\text { to in } \\
\text { the use } \\
\text { of } \\
\text { Techn } \\
\text { ologica } \\
\text { l } \\
\text { equipm } \\
\text { ent in } \\
\text { the } \\
\text { workpl } \\
\text { ace? }\end{array}$ & $\begin{array}{l}\text { 4. Do } \\
\text { you } \\
\text { think } \\
\text { that } \\
\text { trainin } \\
\text { gs in } \\
\text { the use } \\
\text { of IT } \\
\text { are } \\
\text { necessa } \\
\text { ry in } \\
\text { your } \\
\text { compa } \\
\text { ny? }\end{array}$ & $\begin{array}{l}5 . \quad \text { Do } \\
\text { you } \\
\text { think } \\
\text { that } \\
\text { with } \\
\text { the } \\
\text { help of } \\
\text { IT } \\
\text { equipm } \\
\text { ent will } \\
\text { be } \\
\text { increas } \\
\text { ed } \\
\text { work } \\
\text { efficien } \\
\text { cy? }\end{array}$ & $\begin{array}{l}\text { 6. If IT } \\
\text { is } \\
\text { integrat } \\
\text { ed in } \\
\text { HRM, } \\
\text { will the } \\
\text { tasks of } \\
\text { employ } \\
\text { ees be } \\
\text { facilitat } \\
\text { ed? }\end{array}$ & $\begin{array}{l}\text { 7. Jobs } \\
\text { will be } \\
\text { acceler } \\
\text { ated as } \\
\text { process } \\
\text { es by } \\
\text { integrat } \\
\text { ing } \\
\text { tasks } \\
\text { into } \\
\text { HRM } \\
\text { using } \\
\text { IT? }\end{array}$ & $\begin{array}{l}8 . \text { Use } \\
\text { of IT } \\
\text { and } \\
\text { work } \\
\text { techniq } \\
\text { ues will } \\
\text { be } \\
\text { more } \\
\text { success } \\
\text { ful in } \\
\text { your } \\
\text { instituti } \\
\text { on? }\end{array}$ & $\begin{array}{l}\text { 9. The } \\
\text { impact } \\
\text { of IT is } \\
\text { an } \\
\text { import } \\
\text { ant } \\
\text { factor } \\
\text { in } \\
\text { increasi } \\
\text { ng } \\
\text { knowle } \\
\text { dge to } \\
\text { increas } \\
\text { e } \\
\text { efficien } \\
\text { cy in } \\
\text { the }\end{array}$ & $\begin{array}{l}10 . \\
\text { Does } \\
\text { perfor } \\
\text { mance } \\
\text { increas } \\
\mathrm{e} \quad \text { if } \\
\text { there is } \\
\text { advanc } \\
\text { ed } \\
\text { softwar } \\
\text { e and } \\
\text { equipm } \\
\text { ent in } \\
\text { the } \\
\text { implem } \\
\text { entatio } \\
n \text { of }\end{array}$ \\
\hline \multirow[t]{2}{*}{$\mathrm{N}$} & Valid & 56 & 56 & 55 & 56 & 56 & 55 & 56 & 56 & 56 & 56 \\
\hline & Missing & 0 & 0 & 1 & 0 & 0 & 1 & 0 & 0 & 0 & 0 \\
\hline Me & & 2.29 & 2.48 & 1.47 & 1.41 & 1.29 & 1.51 & & 1.20 & 1.86 & 1.25 \\
\hline & & .825 & .809 & .539 & .496 & .530 & .505 & & .401 & .672 & .437 \\
\hline & & -.584 & -1.116 & .479 & .373 & 1.709 & -.037 & & 1.571 & 1.664 & 1.187 \\
\hline & ff Skewness & .319 & .319 & .322 & .319 & .319 & .322 & & .319 & .319 & .319 \\
\hline
\end{tabular}

\section{One way ANOVA}

Below, using statistical techniques and SPSS software we have implemented one way ANOVA analysis. One-way analysis of variance (ANOVA) is a statistical method for testing for differences in the means of three or more groups. As a techniques it use an independent variable or variables variance test factors, where it results to be the most successful analysis relation with our research.

\section{a) Test of Homogeneity of Variances}

4. In your workplace, do you think that training on the use of Information Technology is necessary?

Table 5: Test of Homogeneity of Variances (Source: Author's 2020)

\begin{tabular}{|l|l|l|l|}
\hline Levene Statistic & df1 & df2 & Sig. \\
\hline 2.107 & 2 & 53 & .132 \\
\hline
\end{tabular}

In Table 5, the result of the test of the basic one-way ANOVA assumption, the homogeneity of variance, can be seen. Because here the value of $\mathrm{p}$ (Sig. 0.132) is greater 
than 0.05 , it can be said that the variances are homogeneous. Since the basic assumption of analysis of variance is provided, we can say that in the end the results obtained from the analysis of variance are sound and as such these values are accepted.

\begin{tabular}{|c|c|c|c|c|c|}
\hline \multicolumn{6}{|l|}{ b) ANOVA } \\
\hline \multicolumn{6}{|c|}{$\begin{array}{l}\text { 4. In your workplace, do you think that training on the use of Information Technology } \\
\text { is necessary? }\end{array}$} \\
\hline \multicolumn{6}{|c|}{ Table 6: ANOV A test (Source: Author's 2020) } \\
\hline & Sum of Squares & df & Mean Square & $\mathrm{F}$ & Sig. \\
\hline $\begin{array}{l}\text { Between } \\
\text { Groups }\end{array}$ & .135 & 2 & .067 & .266 & .768 \\
\hline Within Groups & 13.419 & 53 & .253 & & \\
\hline Total & 13.554 & 55 & & & \\
\hline
\end{tabular}

The value of $\mathrm{p}(0.768)$ in the table above is greater than 0.005 , therefore we can say that there is no difference between the groups in the appropriation of the policies of the institution.

\section{c) Multiple Comparisons}

Dependent Variable: 4. In your workplace, do you think that training on the use of Information Technology is necessary?

Table 7.1: Tukey HSD (Source: Author's 2020)

Tukey HSD

\begin{tabular}{|c|c|c|c|c|}
\hline $\begin{array}{l}\text { I) 2. Do you feel threatened by } \\
\text { technology (which could take } \\
\text { up your job)? }\end{array}$ & $\begin{array}{l}\text { (J) } 2 \text {. Do you feel threatened } \\
\text { by technology (which could } \\
\text { take up your job)? }\end{array}$ & $\begin{array}{l}\text { Mean } \\
\text { Difference } \\
(\mathrm{I}-\mathrm{J})\end{array}$ & $\begin{array}{l}\text { Std. } \\
\text { Error }\end{array}$ & Sig. \\
\hline Yes & Maybe yes, maybe no & .169 & .243 & .768 \\
\hline \multicolumn{2}{|l|}{ No } & .033 & .172 & .979. \\
\hline Maybe yes, maybe no & Yes & -.169 & .243 & .768 \\
\hline \multicolumn{2}{|l|}{\begin{tabular}{|l|l|} 
& No \\
\end{tabular}} & -.135 & .207 & .791 \\
\hline No & Yes & -.033 & .172 & .979 \\
\hline \multicolumn{2}{|c|}{ Maybe yes, maybe no } & .135 & .207 & .791 \\
\hline
\end{tabular}

Dependent Variable: 4. Do you think that training in the use of Information Technology is necessary in the company you work for? 
Table 7.2: Tukey HSD (Source: Author's 2020)

\begin{tabular}{|c|c|c|c|}
\hline \multicolumn{4}{|l|}{ Tukey HSD } \\
\hline $\begin{array}{l}\text { (I) 2. Do you feel threatened by } \\
\text { technology (which could take up } \\
\text { your job)? }\end{array}$ & (J) 2. Do you feel threatened & \multicolumn{2}{|c|}{ 95\% Confidence Interval } \\
\hline & & $\begin{array}{l}\text { Lower } \\
\text { Bound }\end{array}$ & $\begin{array}{l}\text { Upper } \\
\text { Bound }\end{array}$ \\
\hline Yes & Maybe yes, maybe no & -.42 & .76 \\
\hline \multicolumn{2}{|r|}{ No } & -.38 & .45 \\
\hline \multirow[t]{2}{*}{ Maybe yes, maybe no } & Yes & -.76 & .42 \\
\hline & No & -.63 & .36 \\
\hline \multirow[t]{2}{*}{ No } & Yes & -.45 & .38 \\
\hline & aybe yes, maybe no & -.36 & .63 \\
\hline
\end{tabular}

Results of the Tukey test are given in the tables below.

From the table above these comparisons are made with the Tukey test rankings.

\subsection{Chi-Square}

\section{Case Processing Summary}

\begin{tabular}{|l|l|l|l|l|l|l|}
\hline & \multicolumn{4}{|l|}{ Cases } & \multicolumn{2}{l|}{} \\
\cline { 2 - 7 } & Valid & \multicolumn{2}{l|}{ Missing } & \multicolumn{2}{l|}{ Total } \\
\cline { 2 - 7 } & $\mathrm{N}$ & Percent & $\mathrm{N}$ & Percent & N & Percent \\
\hline $\begin{array}{l}\text { Gender? * Position in the } \\
\text { institution where you } \\
\text { work? }\end{array}$ & 45 & $80.4 \%$ & 11 & $19.6 \%$ & 56 & $100.0 \%$ \\
\hline
\end{tabular}

Table 8: Chi-Square analysis results, (Source: Author's 2020)

\section{Chi-Square Tests}

\begin{tabular}{|l|l|l|l|}
\hline & Value & df & Asymptotic Significance (2-sided) \\
\hline Pearson Chi-Square & $2.265^{\mathrm{a}}$ & 2 & .322 \\
\hline Likelihood Ratio & 3.261 & 2 & .196 \\
\hline Linear-by-Linear Association & 2.206 & 1 & .138 \\
& & & \\
\hline N of Valid Cases & 45 & & \\
\hline
\end{tabular}

a. 3 cells (50.0\%) bave expected count less than 5. The minimum expected count is 1.09 .

As seen above, the value calculated from SPSS of Pearson Chi-Square is X2 $=2.265$.

The value $\mathrm{X}^{2}$, for the degree of freedom $(\mathrm{v}=2)$ and level of importance $(\alpha=0,05)$ is calculated from the columns "Value" and " $\mathrm{df}$ " where the results of values in total is 4,265. Because 2,265<5,265.

The same result is achieved also the value of Sig. in the table above. Because the value of Asym. Sig. (2-sided) p=0,322>0,05.

Thus, the correlation is homogeneous in terms of success (samples were selected from the same population). 
Comment: According to the results, the Chi-Square Test is significant and shows that there is a relationship between the main issues in which employees are active and their role in developing their knowledge in the use of Information Technology, however, the condition of analysis is not met (3 cells (50.0\%) expect counts less than 5 .

This value must be at least below $20 \%$ ).

Table 8: Symmetric Measures, (Source: Author's 2020)

\begin{tabular}{|l|l|l|l|}
\hline \multicolumn{2}{|l|}{ Symmetric Measures } & Value & Approximate Significance \\
\hline \multirow{2}{|l|}{ Nominal by Nominal } & Phi & .224 & .322 \\
\cline { 2 - 4 } & Cramer's V & .224 & .322 \\
\hline N of Valid Cases & 45 & \\
\hline
\end{tabular}

\section{Conclusion}

The application of IT, nowadays, has a significant growth, which has influenced many different areas which are already in their beginnings of integration of technology to those who already have a basic of knowledge and facilitation for what they do. Meanwhile, information technology has a special impact in the form of HRM in the Public Sector in Republic of Kosovo where it has a very special impact on the performance of tasks and responsibilities that they have. Everyday, in this sector, there are new advancements that enable facilitation in getting things done and achieving better and more efficient results. Therefore, the new applications that are being used today are playing an important role in the implementation of tasks and responsibilities of work in the public sector.

So, IT has changed the approach action and has opened completely new directions in the implementation of applications and practices by facilitating many processes compared to those in the past.

Now, employees based on the results obtained at work do not feel the risk of being replaced, or being victims of technological equipment taking into account the level of education which has increased compared to previous years. This advancement in the use of equipment and applications is constantly advancing and opening new avenues in the creation of techniques for performing daily and practical tasks.

According to the implemented technique in SPSS, One Way ANOVA method is acceptable because of the admitted values according to the criteria which is above the condition 0.005 .

While according to the results, we have 0.132 value of Sig, so that, we reach conclusions that according to the value $\mathrm{P}$ we have 0.768 and we say that there is no difference between groups in adopting the policies of the institution. Through this paper, we highlight that the analysis done using the Chi squares technique are shown to be significant. Also, there are relationships between the main issues in which employees are active, and the importance of their role in developing their knowledge in the use of Information Technology.

Finally, Information Technology as a tool, has greatly facilitated professional work and has managed to provide clear ideas for increasing the need of training by enabling facilitation to be provided in the future. Thus, IT has opened new paths in the efficient and effective 
implementation of tasks that Human Resources have in their daily activities, in the responsibility to implement, in justifying the investments made in technology, and also the increase of trainings for civil servants in public (state) administration.

\section{References}

Alam., J. (2017). Human Resource Information System: a Quality Concept. International Journal of Advanced Research, 5(9), 1423-1427, https://doi.org/10.21474/ijar01/5462 .

Arta JASHARI, Enver KUTLLOVCI. (2020). THE IMPACT OF HUMAN RESOURCE MANAGEMENT PRACTICES ON ORGANIZATIONAL PERFORMANCE CASE STUDY: MANUFACTURING ENTERPRISES IN KOSOVO. Business: Theory and Practice, ISSN 16480627 / eISSN 1822-4202, https://doi.org/10.3846/btp.2020.12001, 222-229.

Comission, E. (2015). Enlargement Strategy and Key Challenges 2014-15. Brussel: EC.

Dery, K., Grant, D., \& Wiblen, S. (2014). Human Resource Information Systems (HRIS): Replacing or Enhancing HRM. Work and Organisational Studies: The University of Sydney.

Dr. Prashanth R. Kaninga et al. (2014). Role of Human Resource Information Systems (HRIS) in Strategic Human Resource Management (SHRM) - A conceptual approach. International Journal in Management \& Social Science.

Kumar, D. (2014). The Use of Information Technology Applications in Human Resource Management in Organizations. International Journal of Emerging Research in Management \& Technology.

Marlene Sofia Alves e Silva, Carlos Guilherme da Silva Lima. (2017). The Role of Information Systems in Human Resource Management. Management of Information Systems, DOI: 10.5772 intechopen.79294.

Niaz, A. (2020, January 16). Impact of Information Technology on Human Resource Management. Retrieved from Profiles Asia Pacific : https://www.profilesasiapacific.com/2020/01/21/informationtechnology-hrm/

Rohilla, J. (2017). Role of Information Technology in Human Resources Management. International Journal of Advance Research, Ideas and Innovations in Technology.

Services, M. o. (2015). Strategy of electronic government 2009-2015. Prishtinë: Ministry of Public Services, Department of Information Technology.

Stone D, Deadrick D, Lukaszewski K, Johnson R. (2015). The influence of technology on the future of human resources management. . Human Resources Management Review, 216-231.

Try Hikmawan, Budi Santoso. (July 2020). HUMAN RESOURCES INFORMATION SYSTEM TO IMPROVE EMPLOYEE PERFORMANCE. Dinasti International Journal of Management Science, $578-584$.

Wilkerson, A. (2015.). The impact of information technology on HRM. 